\title{
GROWTH, YEILD AND QUALITY OF JERUSALEM ARTICHOKE PLANTS UNDER SANDY SOIL CONDITIONS AS AFFECTED BY FOLIAR SPRAY WITH MAGNESIUM AND DIFFERENT RATES OF NITROGEN FERTILIZATION \\ Anwar, R. S. M.* ; E. M. El-Tantawy** and N. T. Soliman* \\ * Veg. Res. Dept., Hort. Res. Inst., Agrice. Res. Center. \\ ** Plant Production Dept.(Vegetables), Fac. Environ. Agric. Sci., El- Arish, Suez Canal Univ., Egypt
}

\begin{abstract}
This work aimed to study the effect of interaction between four $\mathrm{N}$ rates $(100 \%, 75 \%, 50 \%$ and $25 \%$ of recommended dose) and spraying with three rates of Mg (0, $1 \%$, and $2 \%)$ on Jerusalem artichoke plants growth, tuber chemical analysis and tuber yield under sandy soil conditions. The results indicated that application of $100 \%$ or $75 \%$ of recommended $\mathrm{N}$ were the best treatments for increasing plant growth, most of tuber chemical analysis parameters, and tuber yield / plant as well as per feddan. Spraying with $\mathrm{Mg}$ increased all studied parameters compared to control treatment. On the other hand, the best interaction treatments for increasing plant growth, tuber chemical analysis and tuber yield were application of $100 \% \mathrm{~N}+$ spraying with $1 \%$ or $2 \% \mathrm{Mg}$ and application of $75 \% \mathrm{~N}+$ spraying with $1 \% \mathrm{Mg}$ approximately.

Keywords: Jerusalem artichoke, $\mathrm{N}$ fertilization , magnesium foliar application.
\end{abstract}

\section{INTRODUCTION}

Jerusalem artichoke is a native plant of the North American plains cultivated for different purposes in many countries. Jerusalem artichoke accumulates high levels of fructans in their stems and tubers. Fructans and the fructose resulting from fructans hydrolysis can be used in human diet or in medical and industrial applications (Schittenhelm, 1999; Monti et al., 2005). Jerusalem artichoke is considered one of the primary sources for inulin in higher plants (Saengthongpinit and Sajjaanantakul, 2005). Its protein has high food value not only due to the presence of almost all essential amino acids but also due to their good balance (Rakhimov et al., 2003). Jerusalem artichoke is considered a suitable livestock feed (Seiler and Campbell, 2004). In the last decades Jerusalem artichoke has been considered as a biomass crop for ethanol because it commonly produces high levels of carbohydrates (Denoroy, 1996). The possibility of growing Jerusalem artichoke for energy has aroused the scientific interest in this crop (Rodrigues et al., 2007). It is known as a potato for the poor (Pimsaen et al., 2010).

Jerusalem artichoke now attracts the attention of investigators to improve its productivity by application different levels of nitrogen and magnesium especially under sandy soil conditions. Sandy soil had a poor composition and high water infiltration. Under application of high amounts of nitrogen fertilizers especially there were no regulation for application of nitrogen fertilizers and its availability to losses by leaching can affect the under ground water quality which cause a direct risk for human body (Abril 
and Roca, 2008). Nitrogen has a pronounced role in plant metabolism. Nitrogen is a constituent of proteins, enzymes, hormones, vitamins alkaloids, chlorophyll and photosynthesis (Reddy and Reddi, 2002). Nitrogen is considered as one of the major nutrients required by the plants for their growth, development and yield (Singh et al., 2003). The enhancing effect due to the increase in nitrogen dose on plant growth may be attribute to that $\mathrm{N}$ plays major roles in the synthesis of structural proteins and other several macromolecules, in addition to vital contribution in several biochemical process in the plant related to growth (Marschner, 1995). Besides, nitrogen is an important constituent of protoplasm. Also, enzyme the biological catalytic agents, which speed up life processes, have $\mathrm{N}$ as their major constituents (Mengel and Kirkby, 1978). Magnesium plays a vital role in plant, since it is a central atom of the chlorophyll molecule and required in several enzymes involved in phosphate transfer (Marschner, 1995; Reddy and Reddi, 2002) and increased the chlorophyll content in leaves (Bardisi, 2004) leading to high assimilation rate and consequently increase in plant growth. Besides its function in the chlorophyll molecule, $\mathrm{Mg}$ is required in other physiological processes. One major role of $\mathrm{Mg}$ is as a factor in almost enzymes activating phosphorylation structure of ADP or ATP and enzymes molecule (Mengel and Kirkby, 1978).

So, the attempt of this work is to decrease the amount of nitrogen used under application of different levels of magnesium under sandy soil conditions.

\section{MATERIALS AND METHODS}

The present investigation was conducted at the experimental farm ,El kassasein horticultural research station, Ismailia governorate, during two successive seasons of 2009 and 2010, to study the effects of foliar application of magnesium and different rates of mineral nitrogen fertilization on growth, yield and quality of Jerusalem artichoke plants (Helianthus tuberosus L.) Cv. fuseau under sandy soil conditions.Physical and chemical properties of the experimental soil are presented in Table 1.

Table 1: Physical and chemical properties of the experimental soil

\begin{tabular}{|l|c|c|l|c|c|}
\hline \multicolumn{3}{|c|}{ Physical properties } & \multicolumn{3}{c|}{ Chemical properties } \\
\hline & $\mathbf{2 0 0 9}$ & $\mathbf{2 0 1 0}$ & \multicolumn{2}{c|}{$\mathbf{2 0 0 9}$} & $\mathbf{2 0 1 0}$ \\
\hline Sand\% & 96.5 & 95.6 & Organic matter (\%) & 0.03 & 0.08 \\
\hline Silt \% & 1.7 & 1.6 & Available K ppm & 52 & 64 \\
\hline Clay \% & 1.8 & 2.8 & Available P ppm & 5.5 & 6.2 \\
\hline F.C.\% & 6.5 & 6.8 & Available N ppm & 5.4 & 6.9 \\
\hline W.P.\% & 2.4 & 2.5 & Calcium carbonate (\%) & 0.18 & 0.26 \\
\hline Available water & 4.5 & 4.5 & pH & 8.1 & 8.1 \\
\hline Water holding capacity & 13.8 & 14.5 & & & \\
\hline
\end{tabular}

This experiment included twelve treatments, which were the combinations between four doses of soil nitrogen application and foliar application with three levels of magnesium. The treatments were arranged in 
a split-plot design with three replicates, soil application treatments were randomly assigned in the main plots, while foliar spray with magnesium treatments were randomly distributed in the sub-plots as follows:

Soil application

1. $100 \%$ of the recommended dose of mineral nitrogen fertilizer (ammonium sulphate at $300 \mathrm{~kg} / \mathrm{fed}$.)

2. $75 \%$ mineral nitrogen fertilizers (ammonium sulphate $225 \mathrm{~kg} / \mathrm{fed}$.)

3. $50 \%$ mineral nitrogen fertilizers (ammonium sulphate $150 \mathrm{~kg} / \mathrm{fed}$.)

4. $25 \%$ mineral nitrogen fertilizers (ammonium sulphate $75 \mathrm{~kg} / \mathrm{fed}$.)

\section{Foliar application treatments}

1. Control (spraying plants with tap water).

2. Magnesium (1\%)

3. Magnesium (2\%)

Tuber seed of Jerusalem artichoke cultivar (Fuseau) were sown on April $19^{\text {th }}$ in both seasons at $50 \mathrm{~cm}$ apart.

The experiment plot area was $12.6 \mathrm{~m}^{2}$. It contains three dripper lines with $6 \mathrm{~m}$ in long and $70 \mathrm{~cm}$ distance between each two dripper lines. One line was used to measure the vegetative growth parameters and the other two lines were for yield determination .In addition, one row was left between each two experimental plots as a guard area to avoid the overlapping infiltration of soil or spraying application.

Treatments of magnesium foliar application were done for three times; i.e., 60,85 and 110 days from sowing. Each plot received 2l. solution for each level, the untreated plants were sprayed with tap water. The other agricultural practices were carried out as commonly followed in the district.

\section{Data recorded}

Vegetative Growth Characters

A random sample of three plants from each experimental plot was taken at flower initiation stage ( at 120 days after planting ) to calculate plant height $(\mathrm{cm})$, lateral shoots number/ plant, and fresh and dry weight / plant (gm).

\section{Yield and its Components}

At harvest time , 180 days after planting , the total tubers yield /plant $(\mathrm{Kg})$, number of tubers / plant, average tuber weight (gm), total yield (ton / feddan ) and percentage of tuber dry matter (calculated by drying 100 grams of fresh tubers in oven at $70^{\circ} \mathrm{C}$ till a constant weight ).

\section{Tuber Quality}

1. N,P and $K$ contents, total nitrogen, phosphorus and potassium were determined according to mthods described by Bremner and Mulvaney (1982), Olsen and Sommers (1982) and Jackson (1970), respectively .

2. Total carbohydrate (\%); it was determined calorimetrically in fine grained dry tubers by following the method described by Michel et al. (1956).

3. Inulin content was determined in tubers according to the method of Winton and Winton (1985).

Statistical analysis ;

The collected data of this experiment were subjected to proper statistical analysis of variance according to Snedecor and Cochran (1980) 
Anwar, R. S. M. et al.

and means separation were done according to L.S.D. at $5 \%$ level of significance.

\section{RESULTS AND DISCUSSION}

\section{Plant Growth \\ Effect of nitrogen}

Data presented in Table 2 show that application of nitrogen had a significant effect on Jerusalem artichoke growth parameters expressed in plant height, number of branches / plant and fresh as well as dry weight of shoots.

Table 2: Effect of mineral nitrogen fertilization rates on plant growth of Jerusalem artichoke

\begin{tabular}{|l|c|c|c|c|}
\hline \multicolumn{1}{|c|}{ Treatments } & $\begin{array}{c}\text { Plant height } \\
(\mathbf{c m})\end{array}$ & $\begin{array}{c}\text { No. } \\
\text { branches/plant }\end{array}$ & $\begin{array}{c}\text { F.W. shoots/plant } \\
\mathbf{( g )}\end{array}$ & $\begin{array}{c}\text { D.W. shoots/plant } \\
(\mathbf{g})\end{array}$ \\
\hline N rates* & \multicolumn{5}{|c|}{ First season (2009) } \\
\hline $100 \%$ & $201.0 \mathrm{a}$ & $37.67 \mathrm{a}$ & $1343.0 \mathrm{a}$ & $541.1 \mathrm{a}$ \\
\hline $75 \%$ & $196.0 \mathrm{a}$ & $34.00 \mathrm{a}$ & $1208.0 \mathrm{a}$ & $486.8 \mathrm{ab}$ \\
\hline $50 \%$ & $175.6 \mathrm{~b}$ & $29.33 \mathrm{~b}$ & $1058.0 \mathrm{~b}$ & $428.7 \mathrm{~b}$ \\
\hline $25 \%$ & $151.6 \mathrm{c}$ & $24.67 \mathrm{c}$ & $874.0 \mathrm{c}$ & $354.9 \mathrm{c}$ \\
\hline \multicolumn{5}{|c|}{ Second season (2010) } \\
\hline $100 \%$ & $199.7 \mathrm{a}$ & $40.00 \mathrm{a}$ & $1483.0 \mathrm{a}$ & $598.0 \mathrm{a}$ \\
\hline $75 \%$ & $197.0 \mathrm{a}$ & $36.67 \mathrm{ab}$ & $1403.0 \mathrm{a}$ & $565.4 \mathrm{a}$ \\
\hline $50 \%$ & $183.8 \mathrm{~b}$ & $33.00 \mathrm{~b}$ & $1217.0 \mathrm{~b}$ & $490.1 \mathrm{~b}$ \\
\hline $25 \%$ & $166.0 \mathrm{c}$ & $24.00 \mathrm{c}$ & $930.0 \mathrm{c}$ & $437.0 \mathrm{c}$ \\
\hline
\end{tabular}

Values having the same alphabetical letter(s) did not significantly differ at 0.05 level of significance, according to Duncan's multiple range test.

*: The recommended dose $(300 \mathrm{Kg} / \mathrm{fed}$.

The data reveal that all the abovementioned plant growth parameters were increased with increasing nitrogen rates up to the full dose of nitrogen without significant differences with application of $75 \%$ of recommended dose.

The increment in plant growth due to the increase in nitrogen dose might be owe to the pronounced role of nitrogen in plant metabolism. Nitrogen is a constituent of proteins, enzymes, hormones, vitamins alkaloids, chlorophyll and photosynthesis (Reddy and Reddi, 2002). Nitrogen is considered as one of the major nutrients required by the plants for their growth, development and yield (Singh et al., 2003). The enhancing effect due to the increase in nitrogen dose on plant growth may be attributed to that $\mathrm{N}$ plays major roles in the synthesis of structural proteins and other several macromolecules, in addition to vital contribution in several biochemical processes in the plant related to growth (Marschner, 1995). Besides, nitrogen is an important constituent of protoplasm. Also, enzyme the biological catalytic agents, which speed up life processes, have $\mathrm{N}$ as their major constituents (Mengel and Kirkby, 1978).

\section{Effect of magnesium}

Data in Table 3 show that spraying Jerusalem artichoke plant with $\mathrm{Mg}$ at rates of $1 \%$ and $2 \%$ increased plant growth characters; i.e. plant height, number of branches / plant and fresh and dry weights of shoots compared to 
control treatment. Application of $\mathrm{Mg}$ at a rate of $1 \%$ was the superior treatment.

The increment in plant growth due to application of $\mathrm{Mg}$ might be owe to its vital role in plant which it is a central atom of the chlorophyll

molecule and required in several enzymes involved in phosphate transfer (Marschner, 1995: Reddy and Reddi, 2002) and increased the chlorophyll content in leaves (Bardisi, 2004) leading to high assimilation rate, and consequently increase in plant growth.

In this concern, Bari et al.(2001) found that application of $\mathrm{Mg}$ at a rate of $6.5 \mathrm{~kg} \mathrm{Mg} / \mathrm{ha}$. as magnesium oxide had no significant difference with control treatment on potato plant height, number of main stems/hill, and fresh haulm weight/ hill. Application of $\mathrm{Mg}$ at rates of 5, 10 15, and $20 \mathrm{~kg} / \mathrm{ha}$. did not show any significant differences with control treatment on potato plant height and number of shoots/plant (Talukder et al., 2009).

Table 3 : Effect of magnesium foliar spray rates on plant growth of Jerusalem artichoke

\begin{tabular}{|l|c|c|c|c|}
\hline \multicolumn{1}{|c|}{ Treatments } & $\begin{array}{c}\text { Plant height } \\
(\mathbf{c m})\end{array}$ & $\begin{array}{c}\text { No. } \\
\text { branches/plant }\end{array}$ & $\begin{array}{c}\text { F.W. shoots/plant } \\
(\mathbf{g})\end{array}$ & $\begin{array}{c}\text { D.W. shoots/plant } \\
(\mathbf{g})\end{array}$ \\
\hline Mg rates(\%) & \multicolumn{5}{|c|}{ First season (2009) } \\
\hline 0(control) & $174.8 \mathrm{~b}$ & $29.25 \mathrm{~b}$ & $1054.0 \mathrm{~b}$ & $426.4 \mathrm{~b}$ \\
\hline 1 & $187.0 \mathrm{a}$ & $33.00 \mathrm{a}$ & $1165.0 \mathrm{a}$ & $468.9 \mathrm{a}$ \\
\hline 2 & $181.5 \mathrm{ab}$ & $32.00 \mathrm{a}$ & $1144.0 \mathrm{a}$ & $463.3 \mathrm{ab}$ \\
\hline \multicolumn{5}{|c|}{ Second season (2010) } \\
\hline 0 (control) & $180.6 \mathrm{~b}$ & $30.75 \mathrm{~b}$ & $1218.0 \mathrm{~b}$ & $500.7 \mathrm{~b}$ \\
\hline 1 & $191.3 \mathrm{a}$ & $35.25 \mathrm{a}$ & $1285.0 \mathrm{a}$ & $536.0 \mathrm{a}$ \\
\hline 2 & $188.0 \mathrm{a}$ & $34.25 \mathrm{a}$ & $1273.0 \mathrm{a}$ & $531.0 \mathrm{a}$ \\
\hline
\end{tabular}

Values having the same alphabetical letter(s) did not significantly differ at 0.05 level of significance, according to Duncan's multiple range test.

\section{Effect of interaction between mineral nitrogen fertilization and magnesium foliar spray}

Data in Table 4 reveal the effect of interaction between mineral nitrogen and magnesium foliar spray on growth of Jerusalem artichoke plants. The data show that fertilizing Jerusalem artichoke plants with the full dose of $\mathrm{N}$ $(100 \%)$ either alone or with spraying of $\mathrm{Mg}$ at $1 \%$ or $2 \%$ as well as application of $\mathrm{N}$ at $75 \%$ of recommended dose with spraying $\mathrm{Mg}$ at the both doses $(1 \%$ and $2 \% \mathrm{Mg})$ were the best treatments wherein increased the most plant growth parameters as plant height and number of branches in the first season as well as increased fresh and dry weight of branches /plant in the two season. Regarding plant height in the second season, the data illustrate that plant height was significantly increased with application of $100 \% \mathrm{~N}+1 \%$ $\mathrm{Mg}$ and application of $75 \% \mathrm{~N}+1 \% \mathrm{Mg}$. Number of branches in the second season was significantly increased with application of $100 \% \mathrm{~N}+1 \% \mathrm{Mg}$.

It could be concluded that application of $100 \% \mathrm{~N}+$ spraying with $1 \%$ or $2 \% \mathrm{Mg}$ and application of $75 \% \mathrm{~N}+1 \%$ or $2 \% \mathrm{Mg}$ were the best interaction treatments, respectively.

The vital role of nitrogen and $\mathrm{Mg}$ in plant metabolism and their progressive effects on photosynthesis process beyond the increase in plant growth expressed in vegetative growth and plant dry weight. 
Anwar, R. S. M. et al.

4

1210 


\section{Chemical Analysis of Tubers Effect of nitrogen}

The data in Table 5 reveal that application of $100 \%$ of recommended dose was the best treatment for increasing tuber nitrogen content in both seasons. Concerning phosphorus content the same data reveal that application of $100 \% \mathrm{~N}$ was the best treatment in both seasons, but without significant difference with application of $75 \%$ of $\mathrm{N}$ recommended dose in the second season only. This position was reversed with $\mathrm{K}$ content wherein application of $75 \%$ of $\mathrm{N}$ recommended dose was the best treatment in both seasons, but without significant difference with application of $100 \% \mathrm{~N}$ in the second season only.

Carbohydrates and inulin contents were significantly decreased with decreasing nitrogen doses to the lowest dose ( $25 \%$ of recommended dose) in both seasons.

Sawicka (2002) found that inulin content was the highest in objects with application of $\mathrm{N}$ up to $50 \mathrm{~kg} \mathrm{~N}$; dry matter, true protein, fiber and ash contents in Helianthus tuberosus tubers increased up to $100 \mathrm{~kg} \mathrm{~N}$ rate). The highest content of nitrogen, calcium and sodium in Jerusalem artichoke tubers was found at the plots fertilized with a dose of $50 \mathrm{~kg} \mathrm{~N} / \mathrm{ha}$. (Sawicka and Kalembsa, 2008).

\section{Effect of magnesium}

Regarding the effect of spraying with magnesium, the data in Table 6 illustrate that spraying with $2 \% \mathrm{Mg}$ increased $\mathrm{N}$ content in tubers in both seasons without significant difference with spraying $\mathrm{Mg}$ at $1 \%$ in the second season. The same trend was found with $\mathrm{K}$ content. Concerning phosphorus content, the data reveal that spraying plants with $\mathrm{Mg}$ at 1 or $2 \%$ increased $\mathrm{P}$ content in the first season compared to control treatment, while it was not significantly affected in the second season.

Carbohydrates and inulin contents were significantly increased with spraying with $\mathrm{Mg}$ at 1 or $2 \%$ in the second season, but they were not significantly affected in the first season.

Kene et al. (1990) found that magnesium increased NPK uptake in sunflower and promote uptake and translocation of phosphorus (Russell, 1975).

Table 5: Effect of mineral nitrogen fertilization rates on chemical analysis (\%) of Jerusalem artichoke tubers

\begin{tabular}{|l|c|c|c|c|c|}
\hline Treatments & $\mathbf{N}$ & $\mathbf{P}$ & $\mathbf{K}$ & Carbohydrates & Inulin \\
\hline N rates ${ }^{*}$ & \multicolumn{7}{c|}{ First season (2009) } \\
\hline $100 \%$ & $0.563 \mathrm{a}$ & $0.367 \mathrm{a}$ & $2.72 \mathrm{~b}$ & $17.19 \mathrm{a}$ & $10.77 \mathrm{a}$ \\
\hline $75 \%$ & $0.498 \mathrm{~b}$ & $0.358 \mathrm{~b}$ & $2.93 \mathrm{a}$ & $16.83 \mathrm{a}$ & $10.45 \mathrm{ab}$ \\
\hline $50 \%$ & $0.475 \mathrm{c}$ & $0.329 \mathrm{c}$ & $2.75 \mathrm{~b}$ & $16.38 \mathrm{ab}$ & $10.23 \mathrm{ab}$ \\
\hline $25 \%$ & $0.401 \mathrm{~d}$ & $0.316 \mathrm{~d}$ & $2.45 \mathrm{c}$ & $16.12 \mathrm{~b}$ & $9.39 \mathrm{~b}$ \\
\hline \multicolumn{7}{|c|}{ Second season (2010) } \\
\hline $100 \%$ & $0.586 \mathrm{a}$ & $0.384 \mathrm{a}$ & $2.69 \mathrm{a}$ & $17.12 \mathrm{a}$ & $11.18 \mathrm{a}$ \\
\hline $75 \%$ & $0.540 \mathrm{~b}$ & $0.368 \mathrm{a}$ & $2.59 \mathrm{a}$ & $16.65 \mathrm{ab}$ & $10.81 \mathrm{ab}$ \\
\hline $50 \%$ & $0.487 \mathrm{c}$ & $0.332 \mathrm{~b}$ & $2.43 \mathrm{~b}$ & $16.37 \mathrm{ab}$ & $10.35 \mathrm{ab}$ \\
\hline $25 \%$ & $0.423 \mathrm{a}$ & $0.314 \mathrm{c}$ & $1.92 \mathrm{c}$ & $16.07 \mathrm{~b}$ & $10.13 \mathrm{~b}$ \\
\hline
\end{tabular}

Values having the same alphabetical letter(s) did not significantly differ at 0.05 level of significance, according to Duncan's multiple range test.

*: The recommended dose $(300 \mathrm{Kg} / \mathrm{fed}$.) 
Table 6: Effect of magnesium foliar spray rates on chemical analysis (\%) of Jerusalem artichoke tubers

\begin{tabular}{|l|c|c|c|c|c|}
\hline Treatments & $\mathbf{N}$ & $\mathbf{P}$ & $\mathbf{K}$ & Carbohydrates & Inulin \\
\hline Mg rates(\%) & First season (2009) \\
\hline 0(control) & $0.450 \mathrm{c}$ & $0.326 \mathrm{~b}$ & $2.52 \mathrm{c}$ & $16.46 \mathrm{a}$ & $10.25 \mathrm{a}$ \\
\hline 1 & $0.491 \mathrm{~b}$ & $0.357 \mathrm{a}$ & $2.76 \mathrm{~b}$ & $16.74 \mathrm{a}$ & $10.21 \mathrm{a}$ \\
\hline 2 & $0.511 \mathrm{a}$ & $0.351 \mathrm{a}$ & $2.85 \mathrm{a}$ & $16.69 \mathrm{a}$ & $10.17 \mathrm{a}$ \\
\hline \multicolumn{7}{|c|}{ Second season (2010) } \\
\hline 0(control) & $0.486 \mathrm{~b}$ & $0.340 \mathrm{a}$ & $2.06 \mathrm{~b}$ & $16.38 \mathrm{~b}$ & $10.41 \mathrm{~b}$ \\
\hline 1 & $0.524 \mathrm{a}$ & $0.357 \mathrm{a}$ & $2.63 \mathrm{a}$ & $16.66 \mathrm{a}$ & $10.74 \mathrm{a}$ \\
\hline 2 & $0.518 \mathrm{a}$ & $0.352 \mathrm{a}$ & $2.53 \mathrm{a}$ & $16.61 \mathrm{a}$ & $10.69 \mathrm{a}$ \\
\hline
\end{tabular}

Values having the same alphabetical letter(s) did not significantly differ at 0.05 level of significance, according to Duncan's multiple range test.

Effect of interaction between mineral nitrogen fertilization and magnesium foliar spray

Data in Table 7 show the effect of interaction between nitrogen application and magnesium on N, P, K, carbohydrates, and inulin in Jerusalem artichoke tubers. The data reveal that $\mathrm{N}$, carbohydrates, and inulin contents were significantly increased with application of nitrogen at full dose with spraying $\mathrm{Mg}$ at rates of $1 \%$ and $2 \%$. Phosphorus content was increased with application of $\mathrm{N}$ at $50 \%, 75 \%$, and $100 \%$ of $\mathrm{N}$ recommended dose with spraying $\mathrm{Mg}$ at $1 \%$, and $2 \%$ in both seasons.

Table 7: Effect of interaction between mineral nitrogen fertilization and magnesium foliar spray rates on chemical analysis (\%) of Jerusalem artichoke tubers

\begin{tabular}{|c|c|c|c|c|c|c|c|c|c|c|c|}
\hline & 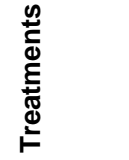 & $\mathbf{z}$ & 口 & $\underline{x}$ & 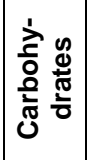 & ․ㅡㅡ & $\mathbf{z}$ & Q & $\underline{Y}$ & 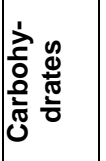 & 点 \\
\hline $\begin{array}{l}\mathrm{N} \\
\text { rates* }\end{array}$ & $\begin{array}{l}\mathrm{Mg} \\
\text { rates(\%) }\end{array}$ & \multicolumn{5}{|c|}{ First season (2009) } & \multicolumn{5}{|c|}{ Second season (2010) } \\
\hline & 0 (control) & $0.520 \mathrm{~b}$ & $0.360 a-d$ & $2.89 \mathrm{~cd}$ & $17.01 \mathrm{~b}$ & $10.54 b$ & $0.560 \mathrm{ab}$ & $0.373 a b c$ & $2.35 d$ & $16.77 a b$ & $10.88 \mathrm{~b}$ \\
\hline $100 \%$ & 1 & $0.595 a$ & $0.395 a$ & $2.25 \mathrm{hi}$ & $17.30 \mathrm{a}$ & $10.95 a$ & $0.610 \mathrm{a}$ & $0.398 a$ & $2.98 a$ & $17.39 a$ & $11.41 \mathrm{a}$ \\
\hline & 2 & $0.575 \mathrm{ab}$ & $0.374 a b$ & $3.02 a b c$ & $17.25 \mathrm{a}$ & $10.81 \mathrm{a}$ & $0.590 \mathrm{a}$ & $0.382 a b$ & $2.76 \mathrm{bc}$ & $17.20 \mathrm{a}$ & $11.25 a$ \\
\hline & 0 (control) & $0.460 \mathrm{c}$ & $0.345 a-d$ & 2.62ef & $16.55 \mathrm{c}$ & $10.35 \mathrm{cde}$ & $0.505 \mathrm{bcd}$ & $0.362 a-d$ & $2.15 \mathrm{e}$ & $16.51 \mathrm{~cd}$ & $10.55 \mathrm{c}$ \\
\hline \multirow[t]{3}{*}{$75 \%$} & 1 & $0.519 \mathrm{~b}$ & $0.370 \mathrm{ab}$ & $3.20 \mathrm{a}$ & $17.02 \mathrm{~b}$ & $10.52 \mathrm{bc}$ & $0.561 \mathrm{ab}$ & $0.374 a b c$ & $2.91 a b$ & $16.76 \mathrm{bc}$ & $10.98 b$ \\
\hline & 2 & $0.515 \mathrm{~b}$ & $0.361 \mathrm{abc}$ & $2.99 \mathrm{bc}$ & $16.92 b$ & $10.47 \mathrm{bcd}$ & $0.555 a b c$ & $0.369 a b c$ & $2.72 \mathrm{c}$ & $16.69 \mathrm{bc}$ & $10.91 b$ \\
\hline & 0 (control) & $0.430 \mathrm{~cd}$ & $0.304 \mathrm{~cd}$ & 2.40gh & $16.22 \mathrm{~d}$ & $10.15 f$ & 0.470def & $0.320 \mathrm{bcd}$ & $2.01 e$ & $16.22 \mathrm{~cd}$ & 10.25ef \\
\hline \multirow[t]{3}{*}{$50 \%$} & 1 & $0.450 \mathrm{~cd}$ & $0.343 a-d$ & 3.10ab & $16.50 \mathrm{c}$ & 10.30def & $0.500 \mathrm{~cd}$ & $0.341 \mathrm{a}-\mathrm{d}$ & $2.68 \mathrm{c}$ & $16.47 \mathrm{~cd}$ & 10.44cd \\
\hline & $2 \%$ & $0.545 \mathrm{ab}$ & $0.341 a-d$ & 2.75de & $16.43 c$ & 10.25 ef & $0.492 \mathrm{de}$ & $0.337 a-d$ & $2.62 c$ & $16.41 \mathrm{~cd}$ & 10.35de \\
\hline & 0 (control) & \begin{tabular}{|l|}
$0.390 \mathrm{~d}$ \\
\end{tabular} & $0.298 \mathrm{~d}$ & \begin{tabular}{|l|}
$2.20 \mathrm{i}$ \\
\end{tabular} & $16.07 \mathrm{~d}$ & $9.97 \mathrm{~g}$ & $0.410 \mathrm{~g}$ & $0.305 d$ & $1.75 f$ & $16.07 \mathrm{~d}$ & \begin{tabular}{|l|}
$9.97 \mathrm{~g}$ \\
\end{tabular} \\
\hline \multirow[t]{2}{*}{$25 \%$} & 1 & $0.402 \mathrm{~cd}$ & $0.320 \mathrm{bcd}$ & \begin{tabular}{|l|}
$2.50 \mathrm{fg}$ \\
\end{tabular} & $16.12 \mathrm{~d}$ & $9.05 \mathrm{~h}$ & $0.425 \mathrm{fg}$ & $0.317 \mathrm{~cd}$ & $1.98 \mathrm{e}$ & $16.04 d$ & $10.15 f$ \\
\hline & 2 & $0.412 \mathrm{~cd}$ & $0.330 \mathrm{bcd}$ & 2.65ef & $16.17 \mathrm{~d}$ & $9.15 \mathrm{~h}$ & $0.435 \mathrm{efg}$ & $0.322 \mathrm{bcd}$ & $2.05 e$ & $16.15 \mathrm{~cd}$ & 10.27def \\
\hline
\end{tabular}

Values having the same alphabetical letter(s) did not significantly differ at 0.05 level of significance, according to Duncan's multiple range test.

*: The recommended dose $(300 \mathrm{Kg} / \mathrm{fed}$.)

Regarding $\mathrm{K}$ content, the data in Table 7 show that application of $75 \% \mathrm{~N}+1 \% \mathrm{Mg}$ recorded the highest value in the first season without 
significant difference with application of $50 \% \mathrm{~N}+1 \% \mathrm{Mg}$. On the other hand, application of $100 \% \mathrm{~N}+1 \% \mathrm{Mg}$ recorded the highest $\mathrm{K}$ content in the second season without significant difference with application of $75 \% \mathrm{~N}+1 \% \mathrm{Mg}$.

\section{Yield}

\section{Effect of nitrogen}

It is obvious from Fig. 1 that dry matter was significantly increased with increasing $\mathrm{N}$ doses up to the highest level $(100 \% \mathrm{~N})$. The contents of dry matter are $21.45 \%$ and $20.71 \%$ for $25 \% \mathrm{~N}$ as well as $22.95 \%$ and $22.40 \%$ for $100 \% \mathrm{~N}$ in the first and second seasons, respectively.

Concerning number of tubers/plant, the data in Table 8 reveal that number of tubers /plant was significantly increased with increasing $\mathrm{N}$ levels up to $75 \%$ of recommended dose in the second season while, it was not significantly affected in the first season. Average tuber weight, yield/plant and yield / fed. were significantly increased with increasing $\mathrm{N}$ levels, wherein application of $\mathrm{N}$ at $75 \%$ and $100 \% \mathrm{~N}$ were the superior treatments in both seasons. The increment in yield / fed. owe to the increment in average tuber weight and yield /plant. Moreover, the increment in tuber yield might be attributed to the pronounced role of nitrogen in plant metabolism. Nitrogen is a constituent of proteins, enzymes, hormones, vitamins alkaloids, chlorophyll and photosynthesis (Reddy and Reddi, 2002) and increasing in vegetative growth as well as dry weight of plant which increased tubers production.

Losavio et al. (1997) found that tuber yield was not significantly affected by nitrogen fertilization. On the other hand, Rodrigues et al. (2007) found that nitrogen application at a rate of $100 \mathrm{~kg} / \mathrm{ha}$. increased dry matter yield, and tuber fresh weight of Jerusalem artichoke plants.

\section{Effect of magnesium}

It is obvious from Fig. 2 that spraying Jerusalem artichoke plants with $\mathrm{Mg}$ at a rate of $1 \%$ increased the content of dry matter in tubers in both seasons $(22.40 \%$ and $21.74 \%$ for the first and second seasons, respectively) without significant difference with spraying $\mathrm{Mg}$ at a rate of $2 \%$ in the second season $(21.66 \%)$.

Regarding number of tubers/plant, the data in Table 9 show that number of tubers/plant was not significantly affected in both seasons. Average tuber weight. yield/plant and yield / fed. were significantly increased with spraying $\mathrm{Mg}$ at 1 or $2 \%$ (Table 9).

The increment in yield due to application of $\mathrm{Mg}$ might be owe much to its vital role in plant which it is a central atom of the chlorophyll molecule and required in several enzymes involved in phosphate transfer (Marschner, 1995: Reddy and Reddi, 2002) and increased the chlorophyll content in leaves (Bardisi, 2004) leading to high assimilation rate and consequently increase in plant growth as well as tuber yield.

In this concern, Bari et al. (2001) found that application of $\mathrm{Mg}$ at a rate of $6.5 \mathrm{~kg} \mathrm{Mg} / \mathrm{ha}$. as magnesium oxide did not show significant difference with control treatment on number of tubers/hill, dry matter of tubers, yield of tubers/hill, yield of tubers/plot and yield of tubers/ha. Talukder et al. (2009) found that application of $\mathrm{Mg}$ at rates of 5, 10,15, and $20 \mathrm{~kg} / \mathrm{ha}$. did not reflect significant differences with control treatment on number of potato tubers/hill,, but tuber weight/hill and tuber yield /ha. were increased with increasing $\mathrm{Mg}$ 
rates up to $10 \mathrm{Kg} / \mathrm{ha}$.,but tuber yield tended to decrease with increasing rate of magnesium.
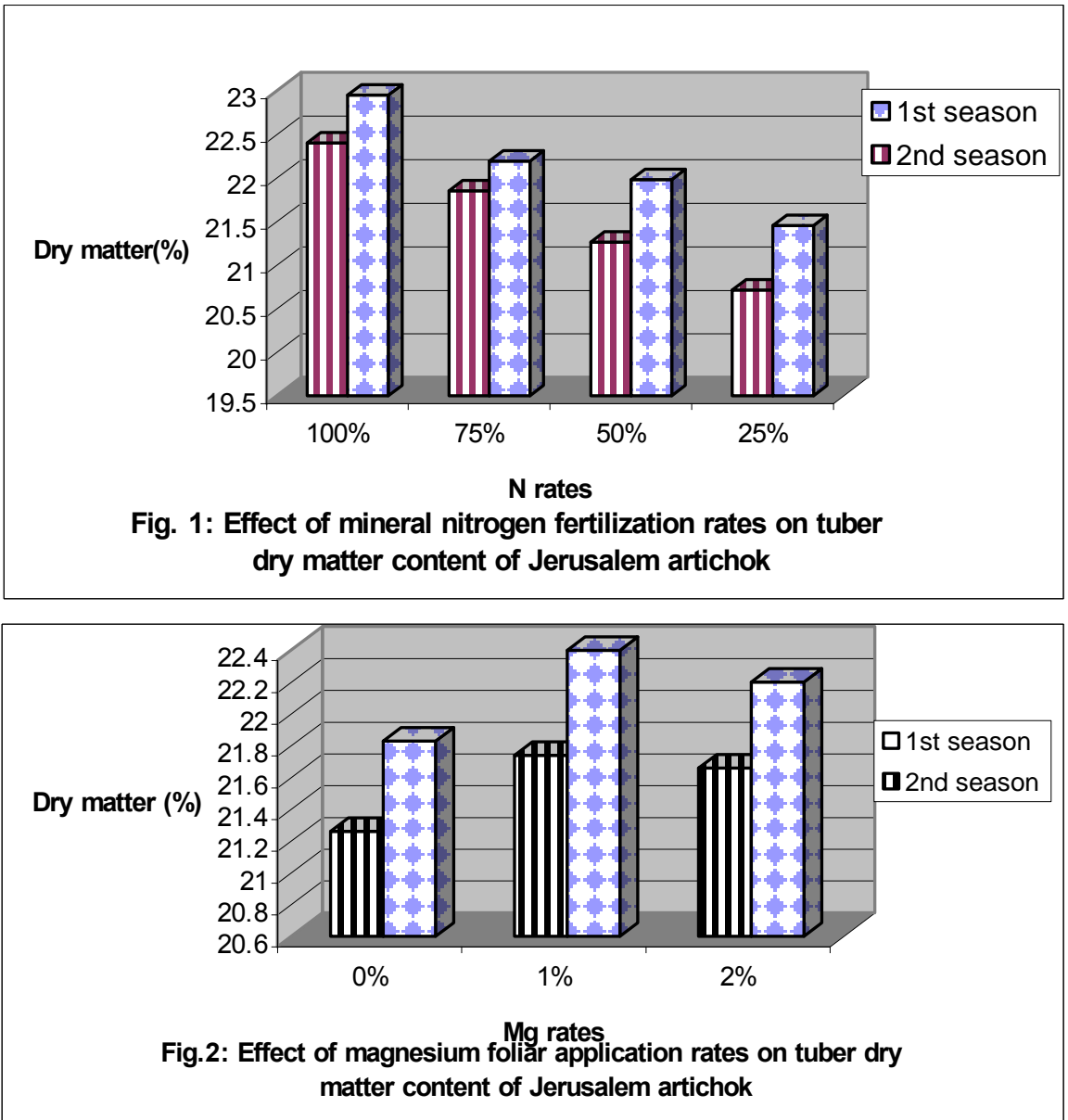

Table 8: Effect of mineral nitrogen fertilization rates on yield of Jerusalem artichoke

\begin{tabular}{|l|c|c|c|c|}
\hline Treatments & No. tubers/plant & $\begin{array}{c}\text { Avg. tuber } \\
\text { weight (g) }\end{array}$ & $\begin{array}{c}\text { Yield/plant } \\
\text { (g) }\end{array}$ & $\begin{array}{c}\text { Yield/fed. } \\
\text { (ton) }\end{array}$ \\
\hline N rates* & \multicolumn{3}{|c|}{ First season (2009) } \\
\hline $100 \%$ & $46.00 \mathrm{a}$ & $40.37 \mathrm{a}$ & $1857.0 \mathrm{a}$ & $22.27 \mathrm{a}$ \\
\hline $75 \%$ & $45.33 \mathrm{a}$ & $38.32 \mathrm{a}$ & $1737.0 \mathrm{a}$ & $20.84 \mathrm{a}$ \\
\hline $50 \%$ & $46.67 \mathrm{a}$ & $32.52 \mathrm{~b}$ & $1516.6 \mathrm{~b}$ & $18.20 \mathrm{~b}$ \\
\hline $25 \%$ & $46.78 \mathrm{a}$ & $28.70 \mathrm{c}$ & $1343.0 \mathrm{c}$ & $16.12 \mathrm{c}$ \\
\hline $\mathbf{2 0 1 0 )}$ Second season \\
\hline $100 \%$ & $42.67 \mathrm{~b}$ & $45.52 \mathrm{a}$ & $1942.0 \mathrm{a}$ & $23.31 \mathrm{a}$ \\
\hline $75 \%$ & $43.33 \mathrm{ab}$ & $42.65 \mathrm{a}$ & $1848.0 \mathrm{a}$ & $22.17 \mathrm{a}$ \\
\hline $50 \%$ & $45.00 \mathrm{a}$ & $36.39 \mathrm{~b}$ & $1637.0 \mathrm{~b}$ & $19.64 \mathrm{~b}$ \\
\hline $25 \%$ & $45.00 \mathrm{a}$ & $32.68 \mathrm{~b}$ & $1470.6 \mathrm{c}$ & $17.64 \mathrm{~b}$ \\
\hline
\end{tabular}

Values having the same alphabetical letter(s) did not significantly differ at 0.05 level of significance, according to Duncan's multiple range test.

*: The recommended dose $(300 \mathrm{Kg} / \mathrm{fed}$.) 
Table 9: Effect of magnesium foliar spray rates on yield of Jerusalem artichoke

\begin{tabular}{|l|c|c|c|c|}
\hline \multicolumn{1}{|c|}{ Treatments } & No. tubers/plant & $\begin{array}{c}\text { Avg. tuber } \\
\text { weight(g) }\end{array}$ & $\begin{array}{c}\text { Yield/plant } \\
\text { (g) }\end{array}$ & $\begin{array}{c}\text { Yield/fed. } \\
\text { (ton) }\end{array}$ \\
\hline Mg rates(\%) & \multicolumn{3}{|c|}{ First season (2009) } \\
\hline 0 (control) & $45.58 \mathrm{a}$ & $32.52 \mathrm{~b}$ & $1482.5 \mathrm{~b}$ & $17.79 \mathrm{~b}$ \\
\hline 1 & $46.25 \mathrm{a}$ & $36.25 \mathrm{a}$ & $1676.5 \mathrm{a}$ & $20.11 \mathrm{a}$ \\
\hline 2 & $46.75 \mathrm{a}$ & $36.27 \mathrm{a}$ & $1695.6 \mathrm{a}$ & $20.34 \mathrm{a}$ \\
\hline \multicolumn{5}{|c|}{ Second season (2010) } \\
\hline 0 (control) & $43.25 \mathrm{a}$ & $37.02 \mathrm{~b}$ & $1633.0 \mathrm{~b}$ & $19.59 \mathrm{~b}$ \\
\hline 1 & $44.25 \mathrm{a}$ & $40.97 \mathrm{a}$ & $1805.0 \mathrm{a}$ & $21.66 \mathrm{a}$ \\
\hline 2 & $44.50 \mathrm{a}$ & $39.94 \mathrm{ab}$ & $1772.0 \mathrm{a}$ & $21.27 \mathrm{a}$ \\
\hline
\end{tabular}
significance, according to Duncan's multiple range test.

Effect of interaction between mineral nitrogen fertilization and magnesium foliar spray

It is obvious from Fig. 3 that application of $100 \% \mathrm{~N}+$ sparing with $1 \% \mathrm{Mg}$ was the superior treatment which recorded the highest record of dry matter content in tubers $(23.55 \%$ and $22.75 \%$ in the first and second seasons, respectively).

Data in Table 10 reveal that number of tubers /plant was not significantly affected in the 1st season, but it was increased with increasing $N$ dose up to $75 \%$ of the recommended $\mathrm{N}+$ spraying $\mathrm{Mg}$ at a rate of $2 \%$ wherein fertilizing with $100 \% \mathrm{~N}+1 \%$ or $2 \% \mathrm{Mg}$ were the best treatments in the second season. Application of high doses of $\mathrm{N}(100 \%$ and $75 \%)+$ spraying with $\mathrm{Mg}$ at $1 \%$ were approximately the best treatments for increasing average tuber weight, yield / plant and total yield / fed. in both seasons.

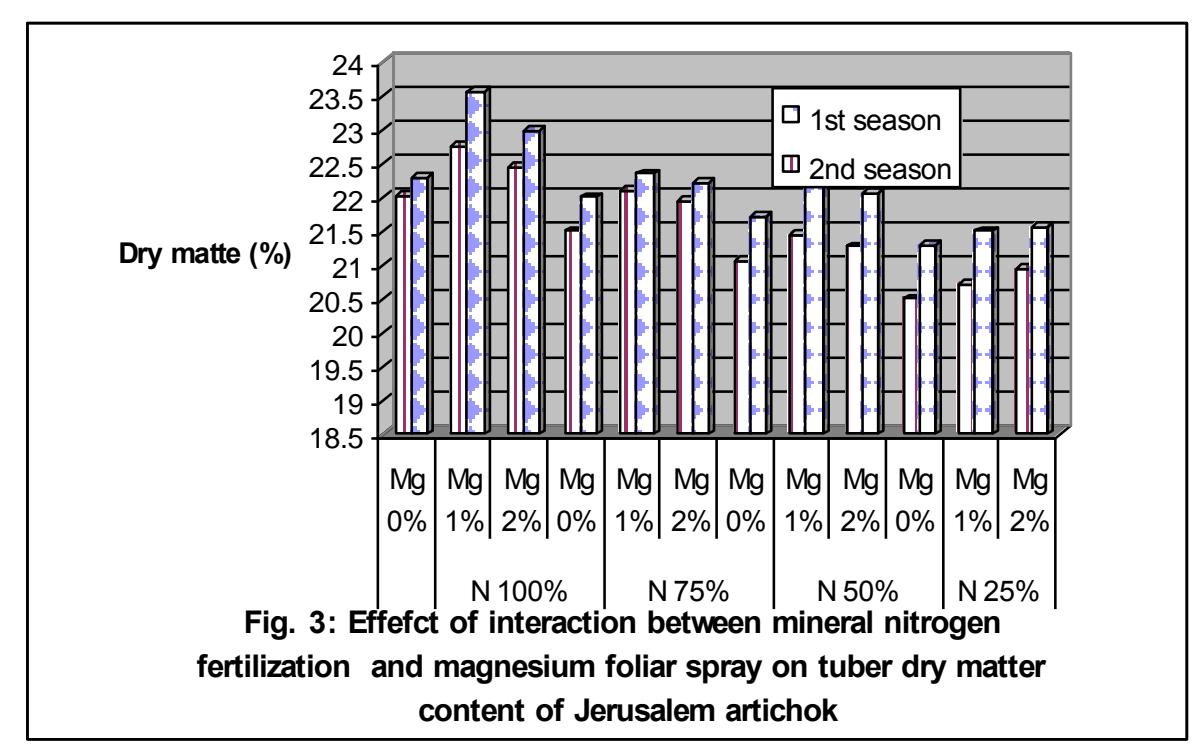


Anwar, R. S. M. et al.

10

1216 


\section{Recommendation:}

It could be recommended from the pervious results that increasing nitrogen dose up to $75 \%$ of recommended dose ( $225 \mathrm{~kg}$ ammonium sulphate /fed.) with spraying of $\mathrm{Mg}$ at a rate of $1 \%$ produced the same yield obtained by $100 \%$ of $\mathrm{N}$ recommended dose.

\section{REFERENCES}

Abril, A. and L. Roca. 2008. Impact of nitrogen fertilization on soil and aquifers in the humid Pampa, Argentina. The Open Agriculture Journal 2:22-27.

Bardisi, A. 2004. Foliar application of magnesium in comparison with kintetin on pea producion under sandy soil conditions. Zagazig J. Agric. Res. 31(4A): 1321-1334.

Bari, M. S.,M.G. Rabbani, M.Sq. Rahman, M.J. Islam and A.T.M.R. Hoque. 2001. Effect of zinc, boron, sulphur, and magnesium on growth and yield of potato. Bakistan J. Biol.Sci. 4(9): 1090-1093.

Bremner, J. M. and C.S. Mulvaney (1982). Total nitrogen In: Page, A. L., R.H.Miller and D. R. Keeney(Eds.). Methods of Soil Analysis. Part 2. Amer. Soc. Agron. Madison, W.I.USA.pp. 595-624.

Denoroy P. 1996. The crop physiology of Helianthus tuberosus L.: a model oriented view. Biomass Bioenerg 11(1): 11-32.

Jackson, M.L. (1970). Soil chemical Analysis. Prentice Hall, Engle wood ceiffs, N.J.

Kene, H.K., S.T. Wankhade and B.N. Sagar. 1990. Influence of nutrient spray on yield and oil content of sunflower. Ann. Plant Physiol. 4(2): 249-251.

Losavio, N., N. Lamascese and A.V. Vonella. 1997. Water requirements and nitrogen fertilization in Jerusalem artichoke (Helianthus tuberosus L.) grown under Mediterranean conditions. Acta Horticulturae 449: II International Symposium on Irrigation of Horticultural Crops.

Marschner, H. 1995. Mineral Nutrition of Higher Plants. $2^{\text {nd }}$ ed., Academic Press Limited, Text Book.

Mengel, K. and E.A. Kirkby. 1978. Principles of Plant Nutrition. International potash institute, P.I. Box, CH-3043. Worbleoufen -Benf/Switzerland.

Michel, K., J.K. Gilles, P. A. Hamilton and F. Smith (1956) . Colorimetric method for determination of sugars and related substances. Analysis chemistry. 28 (3): 350.

Monti, A., T. Amaduccim, and G.Venturi. 2005. Growth response and leaf gas exchange and fructans accumulation of Jerusalem artichoke (Helianthus tuberosus L.) as affected by different water regimes. Eur. J. Agron. 23: 136-145.

Olsen, S.R. and L.E Sommers (1982). Phosphorus . In. Page A.L.R. H. Miller, and D.R.Keeney (Eds.). Methods of Soil Analysis, part2, Amer. Soc. Agron. Madison, W.I. USA. pp. $403-430$. 
Pimsaen, W., S. Jogloy, B. Surihan, T. Kesmala, V. Pensuk and A. Patanothai. (2010). Genotype by Environment ( $G \times E$ ) interaction for yield components of Jerusalem artichoke (Helianthus tuberosus L.). Asian Journal of plant Sciences 9(11): 11-19.

Rakhimov D.A., A.O Arifkhodzhev, L.G. Mezhlumyan, O.M.Yuldashev, U.A. Rozikova, N. Aikhodzhaeva, and M.M. Vakil. 2003. Carbohydrates and proteins from Helianthus tuberosus. Chem. Nat. Comp. 39(3): 312313.

Reddy, T.Y. and G.H.S. Reddi. 2002. Principles of Agronomy. Kalyani Publishers, 3rd ed. $526 \mathrm{pp}$.

Rodrigues, M. A, L. Sousa, J. E. Cabanas and M. Arrobas. 2007. Tuber yield and leaf mineral composition of Jerusalem artichoke (Helianthus tuberosus L.) grown under different cropping practices. Spanish Journal of Agricultural Research ,5(4): 545-553.

Russell, E.W. 1975. Soil Conditions and Plant Growth. 10 $0^{\text {th }}$ ed., Great Britin, William Clowes \& Sons Ltd., London. ELBS, p. 43.

Saengthongpinit W. and T. Sajjaanantakul, 2005. Influence of harvest time and forage temperature on characteristics of inulin from Jerusalem artichoke (Helianthus tuberosus L.) tubers. Postharvest Biol. Technol. 37: 93-100.

Sawicka, B. 2002. Changes in chemical composition of Helianthus tuberosus L. under differentiated nitrogen fertilization. Zeszyty Problemowe Postepow Nauk Rolniczych, number 484: 573-579.

Sawicka, B. and D. Kalembsa. 2008. Variability in macroelement content in tubers of Helianthus tuberosus L. at different nitrogen fertilization levels, Scintiarum Polonorum. Agricultura. 7(1): 67-82.

Schittenhelm, S. 1999. Agronomic performance of root chicory, Jerusalem artichoke, and sugarbeet in stress and nonstress environments. Crop Sci. 39, 1815-1823.

Seiler G.J. and L.G cam bell. 2004. Genetic variability for mineral element concentrations of wild jerusalem artichoke forage. Crop sci 44, 289292 plant production and protection Dep. vegetables faculty of Environmental agricultural sciences.

Singh, S.S., P. Gupta, and A.K. Gupta. 2003. Handbook of Agricultural Sciences. Kalyani Publishers, New Delhi, India. p. 184-185.

Snedecor, G. W. and W. G. Cochran (1980) . Statistical Methods. $7^{\text {th }}$ ed. . lowa State Univ., Press, Amer., lowa, U.S.A.

Talukder, M. A. H., M.B. Islam, S.M.A.H.M. Kamal, M.A. Mannaf and M.M. Uddin. 2009. Effects of magnesium on the performance of potato in the Tista Mender floodplain soil. Bangladish J. Agric. Res. 34(2): 255-261.

Winton, A. L. and K.B. Winton (1985). The analysis of foods. John Wiley and sons. Inc. London. 85 7.P. 


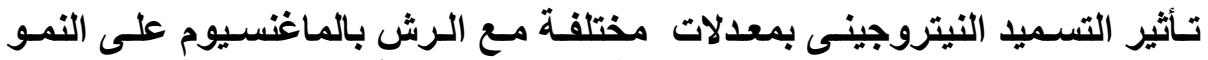

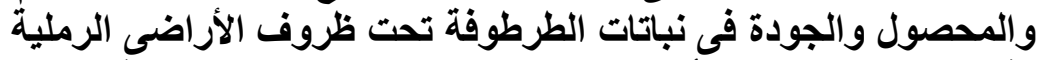

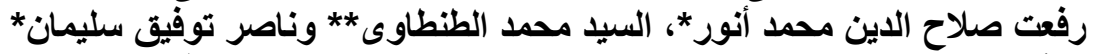

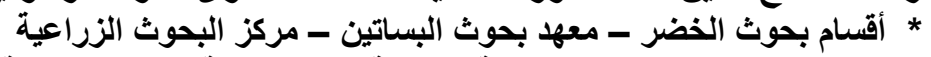
**قسم الإتتاج النباتي ( خضر ) كلية الزراعة للعلوم البيئية بالعريش جامعة قلناة السويس-مصر

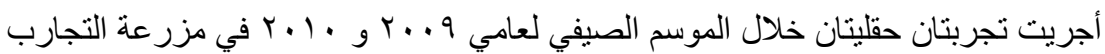

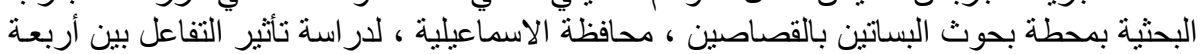

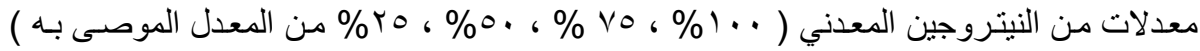

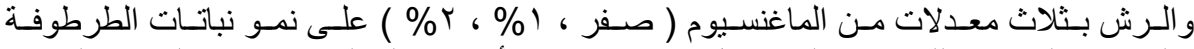

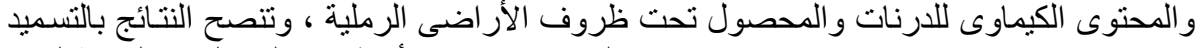

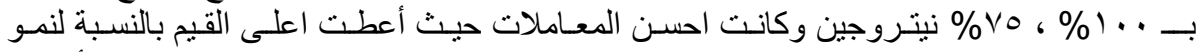

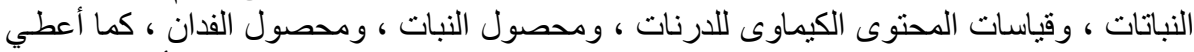

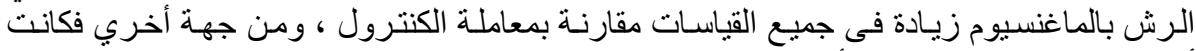

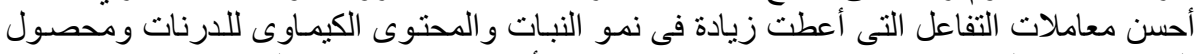

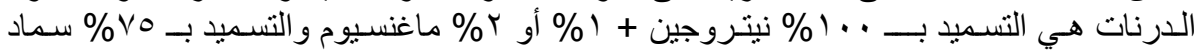

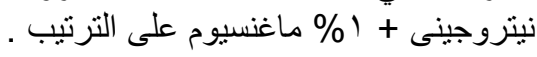

كلية الزراعة - جامعة المنصورة قام بتحكيم البحث كلية الزراعة - جامعة الزقازيث

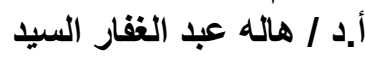
أ.د / الدمتولى عبد السميع الغمرينى الفيد 
Anwar, R. S. M. et al. 
J. Plant Production, Mansoura Univ., Vol. 2 (9): 1205 - 1219, 2011

Table 4 : Effect of interaction between mineral nitrogen fertilization and magnesium foliar spray on plant growth of Jerusalem artichoke

\begin{tabular}{|c|c|c|c|c|c|c|c|c|c|}
\hline \multicolumn{2}{|c|}{ Treatments } & $\begin{array}{c}\text { Plant } \\
\text { height } \\
\text { (cm) }\end{array}$ & $\begin{array}{c}\text { No. } \\
\text { ranches/ } \\
\text { plant }\end{array}$ & $\begin{array}{l}\text { F.W. } \\
\text { shoots/ } \\
\text { plant } \\
\text { (g) }\end{array}$ & $\begin{array}{l}\text { D.W. } \\
\text { shoots/ } \\
\text { plant } \\
\text { (g) }\end{array}$ & $\begin{array}{l}\text { Plant height } \\
\text { (cm) }\end{array}$ & $\begin{array}{c}\text { No. } \\
\text { branches/ } \\
\text { plant }\end{array}$ & $\begin{array}{l}\text { F.W. } \\
\text { shoots/ } \\
\text { plant } \\
\text { (g) }\end{array}$ & $\begin{array}{l}\text { D.W. } \\
\text { shoots/ } \\
\text { plant } \\
\text { (g) }\end{array}$ \\
\hline $\mathrm{N}$ rates & Mg rates(\%) & \multicolumn{4}{|c|}{ First season (2009) } & \multicolumn{4}{|c|}{ Second season (2010) } \\
\hline & 0 (control) & 198.0c & $35.0 \mathrm{ab}$ & $1300.0 \mathrm{ab}$ & $523.7 a b$ & $195.0 \mathrm{c}$ & $38.0 \mathrm{~cd}$ & 1450.0ab & $584.9 a$ \\
\hline \multirow[t]{3}{*}{$100 \%$} & 1 & 205.0a & $40.0 a$ & 1380.0a & $555.8 \mathrm{a}$ & $206.0 a$ & $42.0 \mathrm{a}$ & $1510.0 \mathrm{a}$ & $608.7 a$ \\
\hline & 2 & 200.0ab & $38.0 \mathrm{a}$ & $1350.0 \mathrm{a}$ & $543.8 \mathrm{a}$ & $198.0 \mathrm{~b}$ & $40.0 \mathrm{~b}$ & $1490.0 \mathrm{a}$ & $600.3 a$ \\
\hline & 0 (control) & 189.0d & $32.0 \mathrm{~b}$ & $1120.0 d$ & $451.3 b$ & $190.0 d$ & $34.0 f$ & $1370.0 \mathrm{c}$ & $551.8 b$ \\
\hline \multirow[t]{3}{*}{$75 \%$} & 1 & 203.0ab & $36.0 \mathrm{ab}$ & $1285.0 \mathrm{~b}$ & $517.7 a b$ & $204.0 a$ & $39.0 \mathrm{bc}$ & 1440.0ab & $580.3 a$ \\
\hline & 2 & 196.0c & $34.0 \mathrm{ab}$ & $1220.0 c$ & 491.3ab & 197.0bc & 37.0de & $1400.0 \mathrm{bc}$ & $563.9 \mathrm{~b}$ \\
\hline & 0 (control) & $165.0 f$ & $28.0 \mathrm{bc}$ & $950.0 \mathrm{e}$ & $389.3 c$ & $177.3 f$ & $31.0 \mathrm{~g}$ & $1170.0 \mathrm{e}$ & $471.3 d$ \\
\hline \multirow[t]{3}{*}{$50 \%$} & 1 & $187.0 \mathrm{~d}$ & $31.0 \mathrm{~b}$ & $1115.0 \mathrm{~d}$ & $449.3 b$ & $189.0 d$ & $36.0 \mathrm{e}$ & $1250.0 d$ & $503.6 c$ \\
\hline & 2 & $175.0 \mathrm{e}$ & $29.0 \mathrm{bc}$ & $1110.0 \mathrm{~d}$ & $447.3 b$ & $185.0 \mathrm{e}$ & $32.0 \mathrm{~g}$ & $1230.0 \mathrm{~d}$ & $495.3 c$ \\
\hline & 0 (control) & $147.0 \mathrm{~h}$ & $22.0 \mathrm{c}$ & $847.0 f$ & $341.3 d$ & $160.0 \mathrm{i}$ & $20.0 \mathrm{j}$ & $880.0 \mathrm{~g}$ & $394.6 f$ \\
\hline \multirow[t]{2}{*}{$25 \%$} & 1 & $153.0 \mathrm{~g}$ & $25.0 \mathrm{bc}$ & $878.0 f$ & $352.8 \mathrm{~d}$ & 166.0h & $24.0 \mathrm{i}$ & $940.0 f$ & $451.3 e$ \\
\hline & 2 & $155.0 \mathrm{~g}$ & $27.0 \mathrm{bc}$ & 897.0ef & $370.7 c$ & $172.0 \mathrm{~g}$ & $28.0 \mathrm{~h}$ & $970.0 f$ & $483.3 d$ \\
\hline
\end{tabular}

Values having the same alphabetical letter(s) did not significantly differ at 0.05 level of significance, according to Duncan's multiple range test. *: The recommended dose (300 Kg/fed.) 
Table 10 : Effect of interaction between mineral nitrogen fertilization and magnesium foliar spray on yield of Jerusalem artichoke.

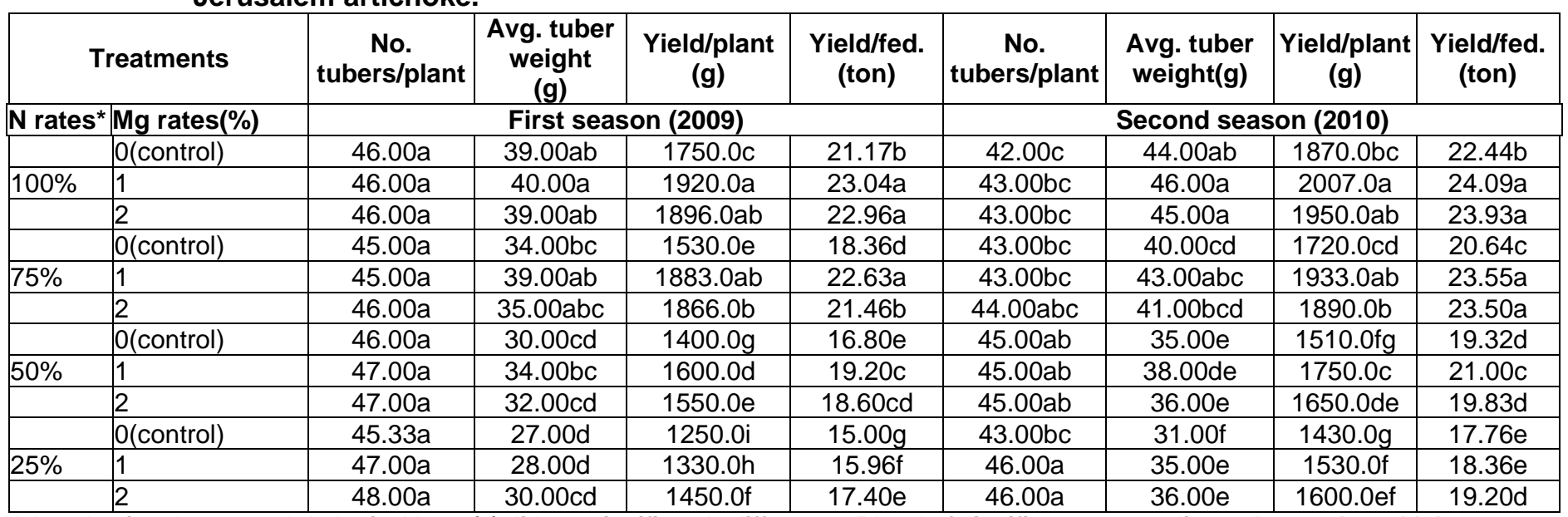

Values having the same alphabetical letter(s) did not significantly differ at 0.05 level of significance, according to Duncan's multiple range test *: The recommended dose $(300 \mathrm{Kg} / \mathrm{fed}$.) 